\title{
Endoscopic submucosal dissection of a squamous cell carcinoma of the esophagus developing in the area of a previous Heller's myotomy for achalasia
}

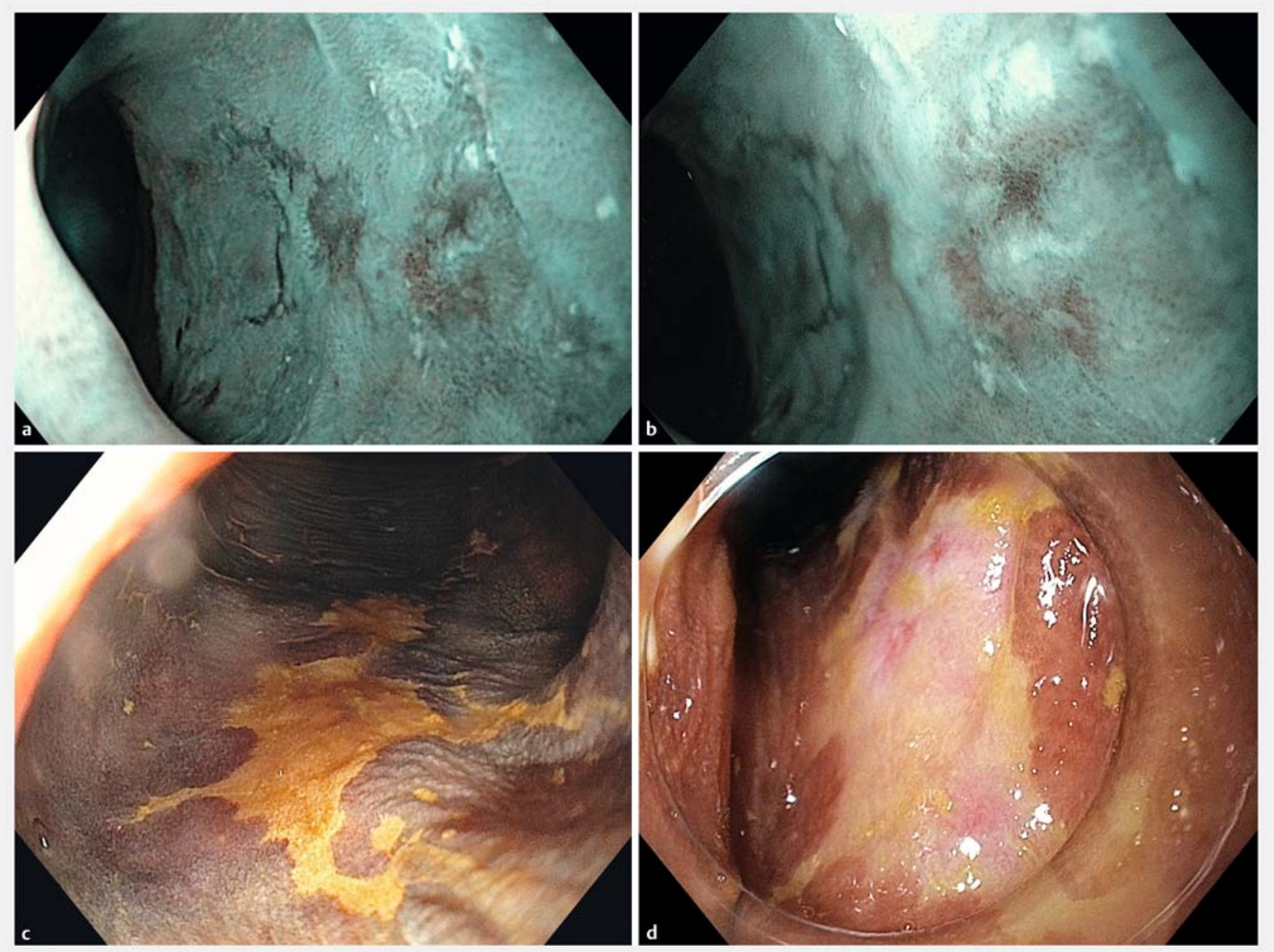

Fig. 1 Endoscopic appearance of the esophageal lesion showing: a, b very mild vessel irregularities on narrow-band imaging; $\mathbf{c}, \mathbf{d}$ an unstained lesion with the pink-color sign after staining with Lugol dye.

Achalasia is considered a risk factor for esophageal cancer; nevertheless, there is no consensus for any regular screening $[1,2]$. A few reports have described early esophageal cancer associated with achalasia that has been resected by endoscopy $[3,4]$. Here we report a case of endoscopic submucosal dissection (ESD) for a squamous cell carcinoma that developed in the area of a previous Heller's myotomy.

A 77-year-old woman with achalasia underwent Heller's myotomy in 2015. In
March 2017 she underwent follow-up endoscopy and a squamous cell carcinoma was detected in the lower third of the esophagus. Examination using magnified narrow-band imaging (NBI) revealed very mild vessel irregularities ( Fig.1a,b), but the use of Lugol dye demonstrated an unstained lesion with the pink-color sign ( $\mathbf{F i g} \cdot \mathbf{1 c}, \mathbf{d}$ ). ESD was successfully performed but the lesion was located on the area of the previous myotomy and there was no circular muscle layer left under the submucosa ( $\triangleright$ Video 1 ; $\triangleright$ Fig. 2 ).
During the procedure, the scarred tissue under the submucosa maintained the structure of the esophageal wall and no perforation occurred. At the end of the procedure, a 24-mm covered metal stent (Taewoong Medical, Seoul, South Korea) was placed and fixed with two clips to avoid delayed perforation.

A subsequent computed tomography (CT) scan showed neither a pneumomediastinum nor signs of esophageal perforation ( $\triangleright$ Fig.3). Pathology confirmed an intramucosal squamous cell carcino- 

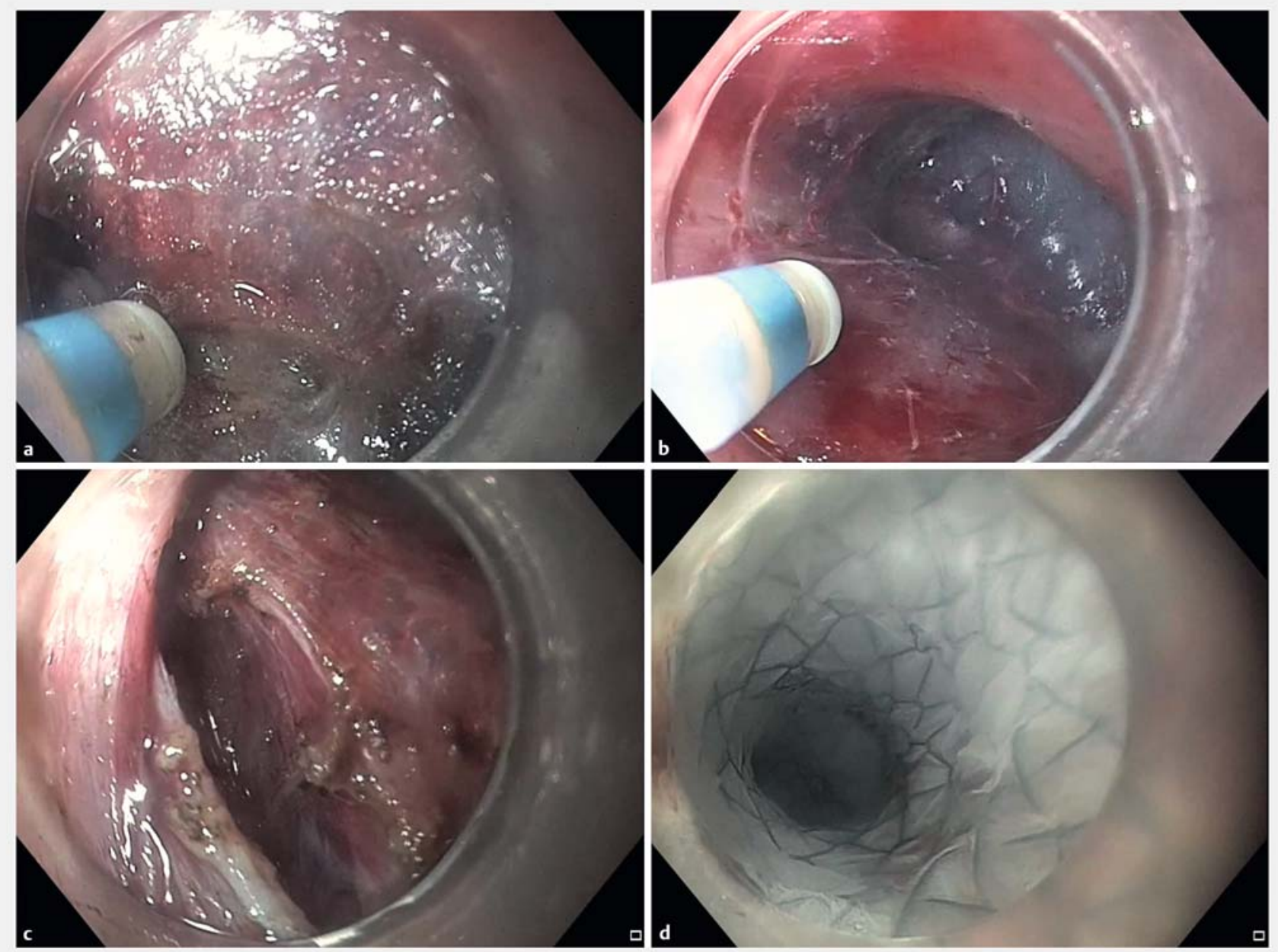

- Fig. 2 Views during the procedure showing: a submucosal fibrosis in the area of the previous Heller's myotomy; $\mathbf{b}$ the tunnel with lower enlargement in the previous myotomy area; $\mathbf{c}$ muscle fibrosis in the area of the previous myotomy; $\mathbf{d}$ a stent positioned to cover the area.

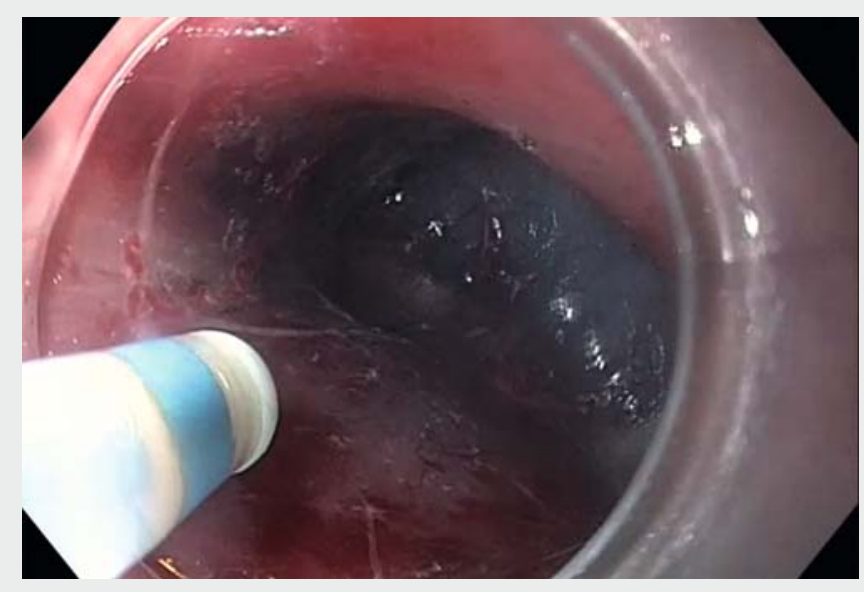

Video 1 Endoscopic submucosal dissection of an esophageal squamous cell carcinoma found in the area of a previous Heller's myotomy, a covered metal stent is placed at the end of the procedure and is subsequently removed 2 weeks later. ma that had been resected with free margins. The patient recovered completely, being able to eat on day 1 , and was discharged on day 3 following the procedure with no delayed morbidity. The stent was removed after 2 weeks because of pain, which disappeared after stent removal.

To our knowledge, this is the first case of ESD for an early esophageal cancer in the area of a previous Heller's myotomy. ESD has been shown to be a safe and effective procedure for early esophageal cancer [5], even in a previously treated achalasia patient [3]. Previous myotomy should not be considered a contraindication to an ESD procedure in such patients, but a prophylactic stent can be placed to reduce the risk of complications.

Endoscopy_UCTN_Code_TTT_1AO_2AI 

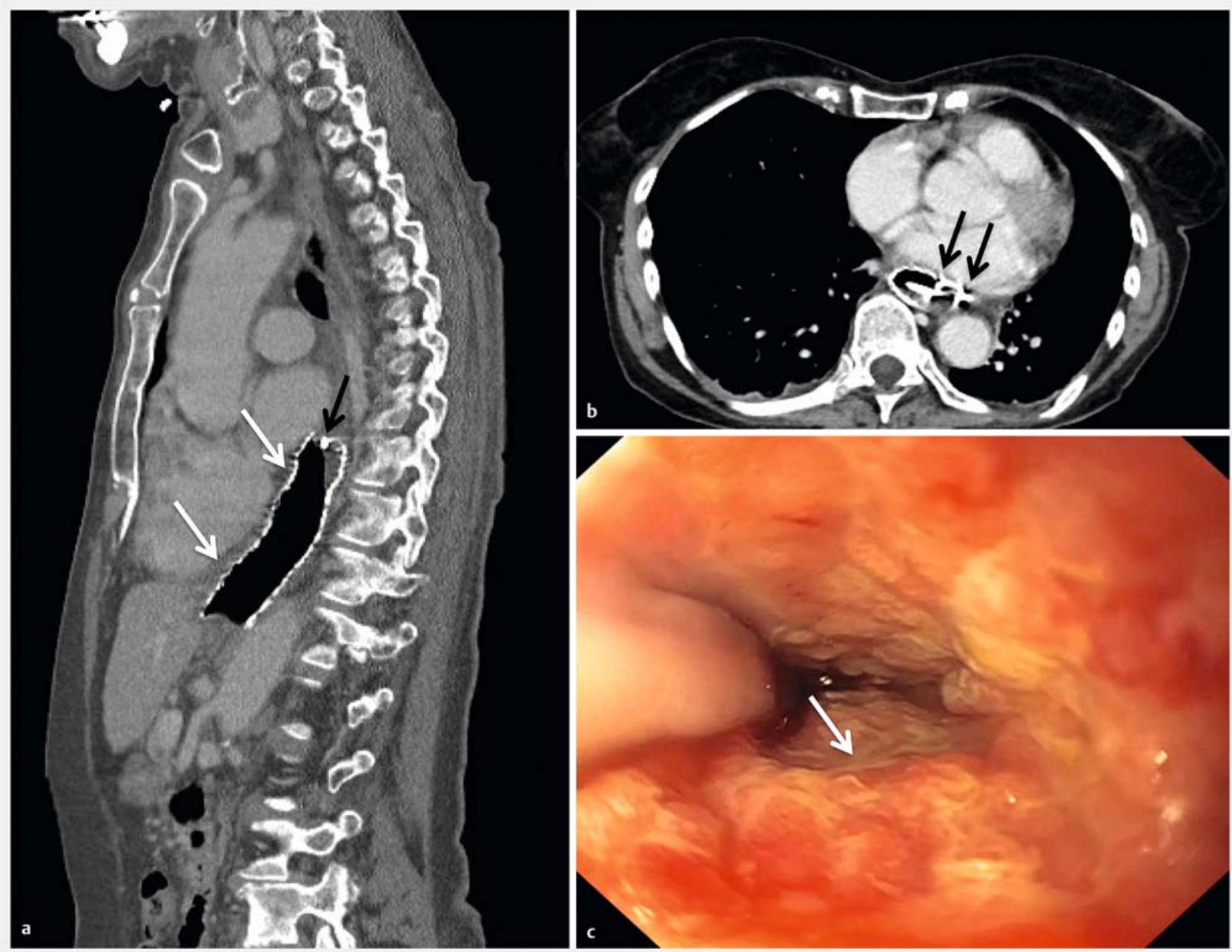

- Fig. 3 Appearances following the procedure: a, b on chest computed tomography, showing a 24-mm covered metal stent (white arrows) fixed with two clips (black arrows) and no evidence of either a pneumomediastinum or esophageal perforation; $c$ on endoscopy after stent removal .

\section{Competing interests}

None
The authors

Dario Biasutto ${ }^{1,2}$, Jérôme Rivory ${ }^{3}$, Sabine Roman ${ }^{1,2,4}$, François Mion ${ }^{1,2,4}$, Jean-

Christophe Saurin ${ }^{3}$, Thierry Ponchon ${ }^{3,4}$, Mathieu Pioche ${ }^{3,4}$

1 Digestive Physiology, Hospices Civils de Lyon, Hôpital Edouard Herriot, Lyon, France

2 Digestive Physiology, Université de Lyon 1, Lyon, France

3 Department of Endoscopy and Gastroenterology, Pavillon L, Hôpital Edouard Herriot, Lyon, France

4 Inserm U1032, LabTAU, Lyon, France

\section{Corresponding author}

Mathieu Pioche, MD

Gastroenterology and Endoscopy, Hôpital Edouard Herriot, 5, place d'Arsonval, 69437 Lyon cedex 03, France

Fax: +33-4-72110147

mathieu.pioche@chu-lyon.fr 


\section{References}

[1] Ravi K, Geno DM, Katzka DA. Esophageal cancer screening in achalasia: is there a consensus? Dis Esophagus 2015; 28: 299 304

[2] Vaezi MF1, Pandolfino JE, Vela MF. ACG clinical guideline: diagnosis and management of achalasia. Am J Gastroenterol 2013; 108: $1238-1249$

[3] Ota M, Narumiya K, Kudo K et al. Incidence of esophageal carcinomas after surgery for achalasia: usefulness of long-term and periodic follow-up. Am J Case Rep 2016; 17: $845-849$

[4] Ohkura Y, lizuka T, Kikuchi D et al. Endoscopic submucosal dissection for early esophageal cancer associated with achalasia. Turk J Gastroenterol 2013; 24: 161 - 166

[5] Kitagawa Y, Suzuki T, Hara T et al. Safety and efficacy of endoscopic submucosal dissection using IT knife nano with clip traction method for early esophageal squamous cell carcinoma. Surg Endosc. doi:10.1007/ s00464-017-5703-x

\section{Bibliography}

DOI https://doi.org/10.1055/s-0043-121565

Published online: 14.11.2017

Endoscopy 2018; 50: E38-E41

(c) Georg Thieme Verlag KG

Stuttgart · New York

ISSN 0013-726X

\section{ENDOSCOPY E-VIDEOS}

https:/|eref.thieme.de/e-videos

回局 Endoscopy E-Videos is a free Fection, reporting 然: on interesting cases and new techniques in gastroenterological endoscopy. All papers include a high quality video and all contributions are freely accessible online.

This section has its own submission website at

https://mc.manuscriptcentral.com/e-videos 